\title{
Influence of vascular endothelial growth factor and alpha-fetoprotein on hepatocellular carcinoma
}

\author{
E.Y. Yvamoto ${ }^{1,2}$, R.F. Ferreira ${ }^{2}$, V. Nogueira ${ }^{2}$, M.A.S. Pinhel ${ }^{2}$, G.D. Tenani², \\ J.G.S.C. Andrade ${ }^{1,2}$, M.E.L. Baitello2, M.L. Gregório ${ }^{2,3}$, P.S. Fucuta ${ }^{1,4}$, \\ R.F. Silva ${ }^{1,4}$, D.R.S. Souza ${ }^{1,2}$ and R.C.M.A. Silva ${ }^{1,4}$ \\ ${ }^{1}$ Faculdade de Medicina de São José do Rio Preto, São José do Rio Preto, SP, Brasil \\ ${ }^{2}$ Núcleo de Pesquisa em Bioquímica e Biologia Molecular, \\ Faculdade de Medicina de São José do Rio Preto, São José do Rio Preto, SP, Brasil \\ ${ }^{3}$ Universidade de Franca, Franca, SP, Brasil \\ ${ }^{4}$ Unidade de Hepatologia, Hospital de Base, FUNFARME/ \\ Faculdade de Medicina de São José do Rio Preto, São José do Rio Preto, SP, Brasil \\ Corresponding author: E.Y. Yvamoto \\ E-mail: erika_yvamoto@hotmail.com
}

Genet. Mol. Res. 14 (4): 17453-17462 (2015)

Received June 24, 2015

Accepted October 8, 2015

Published December 21, 2015

DOI http://dx.doi.org/10.4238/2015.December.21.16

ABSTRACT. We evaluated the influence of the vascular endothelial growth factor (VEGF) -C936T polymorphism on prognosis of hepatocellular carcinoma $(\mathrm{HCC})$, cirrhosis, and hepatitis $\mathrm{C}$ virus (HCV) infection. Serum VEGF and alpha-fetoprotein (AFP) levels were determined and used to characterize sensitivity and specificity. A total of 285 subjects were studied: $68 \mathrm{HCC}, 118$ cirrhosis, $43 \mathrm{HCV}$, and 56 healthy controls. Prevalence of the VEGF -C936T polymorphism and serum levels of VEGF and AFP were analyzed by polymerase chain reaction-restriction fragment length polymorphism and enzyme-linked immunosorbent assay, respectively. The genotype CC (frequencies between 63.24 and $76.79 \%$; P > 0.05) and the $\mathrm{C}$ allele (absolute frequencies from 0.816 to $0.884, \mathrm{P}>0.05$ ) were prevalent in all groups. Higher VEGF levels in HCC patients $(588.0 \pm 501.0 \mathrm{pg} / \mathrm{mL})$ 
were observed, particularly in patients with the T allele in VEGF -C936T $(764.4 \pm 571.7 \mathrm{pg} / \mathrm{mL})$ compared to those in the other groups $(P<0.05)$. The same trend occurred with AFP levels $(\mathrm{HCC}=8.522 \pm 23.830$; cirrhosis $=12.7 \pm 59.3 ; \mathrm{HCV}=4.6 \pm 4.7$; control = $2.7 \pm 1.8 \mathrm{ng} / \mathrm{mL} ; \mathrm{P}=0.005)$. Levels of VEGF and AFP showed sensitivity of 65 and $28 \%$ and specificity of 85 and $99 \%$, respectively, for HCC patients. In conclusion, the VEGF -C936T polymorphism is not associated with $\mathrm{HCC}$ but the mutant allele $(\mathrm{T})$ increases VEGF levels in HCC patients. VEGF could be a potential biomarker for $\mathrm{HCC}$, while AFP could be used to distinguish between patients with HCC and cirrhosis or HCV.

Key words: Hepatocellular carcinoma; Hepatitis C virus; Alpha-fetoprotein; VEGF; Polymorphism; Serum level

\section{INTRODUCTION}

Hepatocellular carcinoma ( $\mathrm{HCC})$ is the most aggressive form of liver cancer and the third leading cause of cancer death globally, accounting for over one million deaths each year (Asghar and Meyer, 2012). More than 626,000 new cases of primary liver cancer are diagnosed per year worldwide, resulting in approximately 598,000 deaths each year. HCC is one of the few cancers with well-defined risk factors. The association between cirrhosis and HCC is well established, with a correlation of over $80 \%$ in Asian patients and $50 \%$ in European patients. The main cause of liver cirrhosis is hepatitis B (HBV) and hepatitis C (HCV) virus infection (Vezozzo et al., 2014), which together account for three-quarters of all cases of HCC worldwide (Gomes et al., 2013). The biomolecular events that trigger HCC carcinogenesis are related to diseases that affect DNA synthesis, such as cirrhosis and HBV and HCV infection (Fattovich et al., 2004). Cirrhosis results in cell proliferation and increased DNA synthesis in regenerative nodules, and these processes can lead to aberrant rearrangements and alterations in regulatory protein function (Schwartz et al., 2007).

There has recently been an accumulation of identified mutations in cancer-related genes and chromosomal alterations that are involved in human carcinogenesis (Venkitaraman, 2014). Therefore, multiple pathways and the combination of genetic and epigenetic events contribute to the abnormal activation or inactivation of various cell signaling pathways, including cell proliferation, cell survival, differentiation, and angiogenesis (Nishida and Goel, 2011). Vascular endothelial growth factor (VEGF) is located at human chromosome 6p21.3 (Kong et al., 2007) and is produced by several cell types, including fibroblasts, smooth muscle cells, hypertrophic chondrocytes and osteoblasts (Ferrara et al., 2003). VEGF is an angiogenesis-promoting factor that plays an important role in the development of cancer and is necessary for primary tumor growth, invasion, and metastasis (Zhang et al., 2012). There are studies showing that single nucleotide polymorphisms (SNPs) in VEGF are a predictive factor of survival in patients with HCC resection (Kong et al., 2007). Based on these studies, it is speculated that SNPs in genes related to angiogenesis, including VEGF, may affect tumor progression and recurrence of the disease in patients after transplantation.

The presence of elevated serum VEGF levels and recurrence of HCC in patients after liver transplantation were closely associated with poor prognosis (Zhan et al., 2013). Additionally, higher alpha-fetoprotein (AFP) levels are detected in patients with chronic liver disease, such as 
hepatitis, cirrhosis or alcohol abuse (van der Veek et al., 2011). AFP is used as a marker for the diagnosis and monitoring of HCC (Chan et al., 2009), where elevated serum AFP levels (>500 ng/ $\mathrm{mL}$ ) are detected in HCC and liver metastases (DiMarino, 2000). Thereby, it is necessary to clarify the influence of genetic alterations involved in the development of $\mathrm{HCC}$, which may differentiate subgroups of patients with HCC from those with cirrhosis and HCV. The aim of this study was to evaluate the influence of the VEGF -C936T polymorphism in patients with HCC, cirrhosis or hepatitis $C$ virus and its relationship to serum levels of VEGF and AFP. In addition, the respective rates of sensitivity and specificity of VEGF and AFP were characterized.

\section{MATERIAL AND METHODS}

\section{Material}

A total of 285 individuals were selected regardless of gender, ethnicity, or age and divided into four groups based on diagnosis: group 1 (G1) consisted of 68 patients with HCC; group 2 (G2) consisted of 118 patients with cirrhosis of any etiology; group 3 (G3) consisted of 43 patients with HCV without cirrhosis; and group 4 (G4) consisted of 56 people without any clinical or biochemical signs of liver disease. Table 1 shows the epidemiological profile of all the groups.

Table 1. Demographic data, lifestyle, comorbidities, and personal history of patients with hepatocellular carcinoma (G1), cirrhosis (G2), or hepatitis C virus (G3), and the control group (G4).

\begin{tabular}{|c|c|c|c|c|c|c|c|c|}
\hline Variables & \multicolumn{2}{|c|}{$\mathrm{G} 1(\mathrm{~N}=68)$} & \multicolumn{2}{|c|}{$\mathrm{G} 2(\mathrm{~N}=118)$} & \multicolumn{2}{|c|}{$\mathrm{G} 3(\mathrm{~N}=43)$} & \multicolumn{2}{|c|}{$\mathrm{G} 4(\mathrm{~N}=56)$} \\
\hline \multicolumn{9}{|l|}{ Age (years) } \\
\hline Minimum & \multicolumn{2}{|c|}{26} & \multicolumn{2}{|c|}{16} & \multicolumn{2}{|c|}{25} & \multicolumn{2}{|c|}{24} \\
\hline \multirow[t]{2}{*}{ Maximum } & \multicolumn{2}{|c|}{82} & \multicolumn{2}{|c|}{77} & \multicolumn{2}{|c|}{84} & \multicolumn{2}{|c|}{81} \\
\hline & $\mathrm{N}$ & $\%$ & $\mathrm{~N}$ & $\%$ & $\mathrm{~N}$ & $\%$ & $\mathrm{~N}$ & $\%$ \\
\hline \multicolumn{9}{|l|}{ Gender } \\
\hline Female & 17 & 25 & 32 & 27.1 & 16 & 37.2 & 25 & 44.6 \\
\hline Male & 51 & 75 & 86 & 72.9 & 27 & 62.8 & 31 & 55.4 \\
\hline \multicolumn{9}{|l|}{ BMI $\left(\mathrm{kg} / \mathrm{m}^{2}\right)$} \\
\hline Underweight $(<18.5)$ & 0 & 0 & 0 & 0 & 4 & 9.30 & 0 & 0 \\
\hline Normal weight (18.5-24.9) & 29 & 42.6 & 41 & 34.75 & 15 & 34.88 & 21 & 37.5 \\
\hline Overweight (25-29.9) & 20 & 28.4 & 45 & 38.14 & 17 & 39.53 & 16 & 28.57 \\
\hline Obese $(>30.0)$ & 11 & 16.18 & 29 & 24.57 & 5 & 11.63 & 16 & 28.57 \\
\hline No information & 8 & 11.76 & 3 & 2.54 & 2 & 4.65 & 3 & 5.35 \\
\hline Alcohol (>20 g/day) & 32 & 47.1 & 57 & 48.3 & 16 & 37.2 & 3 & 5.4 \\
\hline Pesticides & 26 & 38.2 & 35 & 29.7 & 17 & 39.5 & 6 & 10.7 \\
\hline Previous liver diseases & 7 & 10.3 & 10 & 8.47 & 1 & 2.33 & 2 & 3.6 \\
\hline Hypertension & 21 & 30.9 & 33 & 28 & 18 & 41.9 & 20 & 35.7 \\
\hline Diabetes & 22 & 32.4 & 43 & 36.4 & 8 & 18.6 & 5 & 8.9 \\
\hline Family history of HCC & 4 & 5.89 & 9 & 7.63 & 2 & 4.7 & 0 & 0 \\
\hline
\end{tabular}

$\mathrm{N}=$ number of individuals; body mass index (BMI).

All patients were treated at the Ambulatory Center of Gastroenterology and Clinical Cancer Institute (ICA) of Hospital de Base - University Medical Centre (HB)/Medical School of São José do Rio Preto (FAMERP), SP, Brazil. HCC was diagnosed in compliance with the practice guidelines of the American Association for the Study of Liver Disease (AASLD), which includes imaging studies (computerized tomography scan and/or magnetic resonance imaging), serologic test for alpha-fetoprotein (AFP), and a biopsy to look for hepatic nodules $\geq 1 \mathrm{~cm}$ in diameter in case of inconclusive imaging diagnosis (Bruix and Sherman, 2011). A liver biopsy or the combination of clinical, endoscopic, and imaging data confirmed the diagnosis of cirrhosis. HCV without cirrhosis 
was detected by an anti-HCV test with the electrochemiluminescence immunoassay method (ECLIA-Roche Cobas E601). The positive result was confirmed by chemiluminescence (Abbott ARCHITECT i4000). The control group was selected in clinics of other specialties and/or blood bank/HB/FAMERP, and included subjects without clinical or biochemical signs of liver disease. All participants were informed of the characteristics of the study and signed an informed consent form. This project was approved by the Research Ethics Committee of the Medical School of São José do Rio Preto (CEP/FAMERP - Process: 435/2011).

\section{Methods}

Genomic DNA extraction and amplification of the VEGF -C936T polymorphic fragment was done using the set of primers: Forward 5'-AAG GAA GAG GAG ACT CTG CGC-3' and Reverse 5'-TAT GTG GGT GGG TGT GTC TAC AGG-3'. This protocol has been described elsewhere (Wolf et al., 2004).

The serum concentration of VEGF and AFP was obtained using an enzyme-linked immunosorbent assay (ELISA; R\&D System, Inc., Minneapolis, MN, USA) following the manufacturer instructions. The references values were as follows: VEGF $\geq 220 \mathrm{pg} / \mathrm{mL}$ (manufacturer instructions) and AFP $\geq 200 \mathrm{ng} / \mathrm{mL}$ (Chan et al., 2014).

\section{Statistical analysis}

Parametric and non-parametric methods were used depending on the nature of the variables involved, including the Fisher exact test, the chi-square test, the Student $t$-test, HardyWeinberg equilibrium, receiver operator characteristic (ROC) curve, box plot, or Pearson correlation. Differences were considered to be significant when $\mathrm{P}$ value $<0.05$.

\section{RESULTS}

The distribution of genotype and allele frequencies of the VEGF -C936T polymorphism is shown in Table 2, highlighting the prevalence of the homozygous wild-type (CC) genotype and the $\mathrm{C}$ allele in all groups $(\mathrm{P}>0.05)$. There was a similar distribution for genotypes with at least one mutant allele (-/T) and the absolute frequency of the T allele in all groups (G1-37\%, 0.18; G2-24\%; 0.12 ; G3-28\%; 0.14 and G4-23\%; 0.11; P > 0.05 for all groups). The Hardy-Weinberg equilibrium was observed in the groups with $\mathrm{HCC}\left(\chi^{2}=3.45 ; 0.10<\mathrm{P}<0.05\right)$, cirrhosis $\left(\chi^{2}=0.45 ; \mathrm{P}=0.50\right)$, $\mathrm{HCV}\left(\chi^{2}=1.13 ; 0.25<\mathrm{P}<0.5\right)$ and the control group $\left(\chi^{2}=0.97 ; 0.75<\mathrm{P}<0.9\right)$.

The analysis of the association between the VEGF -C936T polymorphism and VEGF serum levels (Table 2) showed higher values in patients with HCC carrying at least one mutant allele $(-/ \mathrm{T})(\mathrm{G} 1=764.4 \pm 571.7 \mathrm{pg} / \mathrm{mL})$ compared with that in cirrhosis patients $(\mathrm{G} 2=128.9 \pm 64.7$ $\mathrm{pg} / \mathrm{mL} ; \mathrm{P}=0.004)$, HCV patients $(\mathrm{G} 3=289.8 \pm 199.0 \mathrm{pg} / \mathrm{mL} ; \mathrm{P}=0.034)$, and the control group (G4 = $216.8 \pm 187.3 \mathrm{pg} / \mathrm{mL} ; \mathrm{P}=0.011)$. The intra-group analysis showed similarity in serum VEGF levels for both genotypes (CC vs -/T; P > 0.05).

Table 3 shows higher serum VEGF levels in patients with HCC (G1 = 588.0 \pm 501.0 pg/ $\mathrm{mL})$, compared to patients with cirrhosis $(\mathrm{G} 2=173.0 \pm 113.0 \mathrm{pg} / \mathrm{mL})$, patients with HCV $(\mathrm{G} 3=$ $273.0 \pm 189.0 \mathrm{pg} / \mathrm{mL})$ and the control group $(\mathrm{G} 4=264.0 \pm 194.0 \mathrm{pg} / \mathrm{mL})(\mathrm{P}<0.02$ for all groups). The same trend occurred in patients with cirrhosis compared to the control group $(P=0.037)$. For 
the serum AFP level, HCC patients showed higher levels (G1 $=8.522 \pm 23.830 \mathrm{ng} / \mathrm{mL}$ ) compared to all other groups $(\mathrm{G} 2=12.7 \pm 59.3 \mathrm{ng} / \mathrm{mL} ; \mathrm{G} 3=4.6 \pm 4.7 \mathrm{ng} / \mathrm{mL} ; \mathrm{G} 4=2.7 \pm 1.8 \mathrm{ng} / \mathrm{mL} ; \mathrm{P}=$ 0.005 for all groups). The same trend occurred in patients with cirrhosis (G2) compared to patients with $\mathrm{HCV}(\mathrm{G} 3 ; \mathrm{P}=0.045)$. High levels of VEGF prevailed among patients with $\mathrm{HCC}(\mathrm{G} 1=70 \%)$ compared to patient with cirrhosis $(G 2=30 \% ; P=0.02)$ (Table 3). The same was observed for high levels of AFP in patients with $\mathrm{HCC}(\mathrm{G} 1=32 \%)$ when compared with the other groups ( $\mathrm{G} 2=1 \%$; $\mathrm{G} 3=0 \% ; \mathrm{G} 4=0 \% ; \mathrm{P}<0.0004$ for all groups; Table 3).

Table 2. Distribution of genotype and allele frequencies and serum levels of VEGF for the VEGF -C936T polymorphism in patients with hepatocellular carcinoma (G1), cirrhosis (G2), or hepatitis C virus (G3), and the control group (G4).

\begin{tabular}{|c|c|c|c|c|c|c|c|c|}
\hline \multirow{2}{*}{$\begin{array}{l}\text { VEGF -C936T } \\
\text { Genotype }\end{array}$} & \multicolumn{2}{|c|}{$\mathrm{G} 1(\mathrm{~N}=68)$} & \multicolumn{2}{|c|}{$\mathrm{G} 2(\mathrm{~N}=118)$} & \multicolumn{2}{|c|}{$\mathrm{G} 3(\mathrm{~N}=43)$} & \multicolumn{2}{|c|}{$\mathrm{G} 4(\mathrm{~N}=56)$} \\
\hline & $\mathrm{N}$ & $\%$ & $\mathrm{~N}$ & $\%$ & $\mathrm{~N}$ & $\%$ & $\mathrm{~N}$ & $\%$ \\
\hline $\mathrm{CC}$ & 43 & 63.24 & 90 & 76.27 & 31 & 72.09 & 43 & 76.79 \\
\hline TC & 25 & 36.76 & 27 & 22.88 & 12 & 27.91 & 13 & 23.21 \\
\hline TT & 0 & 0 & 1 & 0.85 & 0 & 0 & 0 & 0 \\
\hline$-/ T$ & 25 & 36.76 & 28 & 23.73 & 12 & 27.91 & 13 & 23.21 \\
\hline Total & 68 & 100 & 118 & 100 & 43 & 100 & 56 & 100 \\
\hline \multicolumn{9}{|c|}{ Allelic frequency } \\
\hline Allele & $\mathrm{N}$ & Abs. Freq. & $\mathrm{N}$ & Abs. Freq. & $\mathrm{N}$ & Abs. Freq. & $\mathrm{N}$ & Abs. Freq \\
\hline c & 111 & 0.816 & 207 & 0.877 & 74 & 0.861 & 99 & 0.884 \\
\hline $\mathrm{T}$ & 25 & 0.184 & 29 & 0.123 & 12 & 0.140 & 13 & 0.116 \\
\hline Total & 136 & 1 & 236 & 1 & 86 & 1 & 112 & 1 \\
\hline \multicolumn{9}{|l|}{ Serum levels } \\
\hline Genotype & \multicolumn{2}{|c|}{ (N) $\mathrm{M} \pm \mathrm{SD}$} & \multicolumn{2}{|c|}{ (N) $\mathrm{M} \pm \mathrm{SD}$} & \multicolumn{2}{|c|}{ (N) $\mathrm{M} \pm \mathrm{SD}$} & \multicolumn{2}{|c|}{ (N) $\mathrm{M} \pm \mathrm{SD}$} \\
\hline $\mathrm{CC}$ & & \multicolumn{2}{|c|}{ (14) $191.9 \pm 126$} & \multicolumn{2}{|c|}{ (16) $268.8 \pm 192.5$} & \multicolumn{2}{|c|}{ (25) $277.5 \pm 197.4$} \\
\hline$-/ T$ & \multicolumn{2}{|c|}{$\begin{array}{l}\text { (11) } 37.2 .4 \pm 5717 \\
\text { (11) } 764.471\end{array}$} & \multicolumn{2}{|c|}{ (6) $128.9 \pm 64.7$} & \multicolumn{2}{|c|}{ (4) $289.8 \pm 199$} & \multicolumn{2}{|c|}{ (7) $216.8 \pm 187.3$} \\
\hline
\end{tabular}

${ }^{*}$ Fisher exact test or chi-square and Student $t$-test: all values $\mathrm{P}>0.05$, except for -/T: G1 $\neq$ G2 (P=0.004); G1 $\neq$ G4 (P $=0.011) . \mathrm{VEGF}=$ vascular endothelial growth factor; Abs. Freq. = absolute frequency; $\mathrm{N}=$ number of individuals; $\mathrm{M}=$ means; SD = standard deviation.

Table 3. Frequency of patients with hepatocellular carcinoma (G1), cirrhosis (G2), or hepatitis C virus (G3), and the control group (G4) with altered levels of vascular endothelial growth factor (VEGF) or alpha-fetoprotein (AFP).

\begin{tabular}{|c|c|c|c|c|c|c|c|c|c|c|c|c|c|c|}
\hline \multirow[t]{2}{*}{ Variables } & \multicolumn{2}{|c|}{$\mathrm{G} 1(\mathrm{~N}=20)$} & \multicolumn{2}{|c|}{$\mathrm{G} 2(\mathrm{~N}=20)$} & \multicolumn{2}{|c|}{$\mathrm{G} 3(\mathrm{~N}=20)$} & \multicolumn{2}{|c|}{$\mathrm{G} 4(\mathrm{~N}=32)$} & \multicolumn{6}{|c|}{$P$} \\
\hline & & & & & & & & & $(\mathrm{G} 1 \times \mathrm{G} 2)$ & $(\mathrm{G} 1 \times \mathrm{G} 3)$ & $(\mathrm{G} 1$ × G4) & $(\mathrm{G} 2 \times \mathrm{G} 3)$ & $(\mathrm{G} 2 \times \mathrm{G} 4)$ & $(\mathrm{G} 3 \times \mathrm{G} 4)$ \\
\hline \multirow[t]{2}{*}{ VEGF serum level (pg/mL) } & M & SD & M & SD & M & SD & M & SD & & & & & & \\
\hline & 588.0 & 501.19 & 173.0 & 113.31 & 273.0 & 188.65 & 264.2 & 193.94 & $0.001^{*}$ & $0.014^{*}$ & $0.011^{\star}$ & 0.050 & $0.037^{*}$ & 0.873 \\
\hline \multirow{4}{*}{$\begin{array}{l}\text { Frequency of individuals } \\
\geq 220 \mathrm{pg} / \mathrm{mL} \\
<220 \mathrm{pg} / \mathrm{mL}\end{array}$} & $\mathrm{N}$ & $\%$ & $\mathrm{~N}$ & $\%$ & $\mathrm{~N}$ & $\%$ & $\mathrm{~N}$ & $\%$ & & & & & & \\
\hline & 14 & 70 & 6 & 30 & 11 & 55 & 16 & 70 & $0.026^{*}$ & 0.513 & 0.257 & 0.200 & 0.257 & 0.947 \\
\hline & 6 & 30 & 14 & 70 & 9 & 45 & 16 & 30 & & & & & & \\
\hline & \multicolumn{2}{|c|}{$\mathrm{G} 1(\mathrm{~N}=66)$} & \multicolumn{2}{|c|}{$\mathrm{G} 2(\mathrm{~N}=100)$} & \multicolumn{2}{|c|}{$\mathrm{G} 3(\mathrm{~N}=27)$} & \multicolumn{2}{|c|}{$\mathrm{G} 4(\mathrm{~N}=48)$} & & & & & & \\
\hline \multicolumn{15}{|l|}{ AFP serum level (ng/mL) } \\
\hline & 8.522 .4 & 23.830 & 12.6 & 59.26 & 4.6 & 4.67 & 2.7 & 1.77 & $0.005^{*}$ & $0.005^{*}$ & $0.005^{*}$ & $0.045^{*}$ & 0.182 & 0.094 \\
\hline \multirow{3}{*}{$\begin{array}{l}\text { Frequency of individuals } \\
\geq 200 \mathrm{ng} / \mathrm{mL} \\
<200 \mathrm{ng} / \mathrm{mL}\end{array}$} & $\mathrm{N}$ & $\%$ & $\mathrm{~N}$ & $\%$ & $\mathrm{~N}$ & $\%$ & $\mathrm{~N}$ & $\%$ & & & & & & \\
\hline & 21 & 32 & 1 & 1 & 0 & 0 & 0 & 0 & $<0.0001^{*}$ & $0.0003^{*}$ & $<0.0001^{*}$ & * 1.000 & 1.000 & 1.000 \\
\hline & 45 & 68 & 99 & 99 & 27 & 100 & 48 & 100 & & & & & & \\
\hline
\end{tabular}

Student $t$-test, Fisher exact test or chi-square test. ${ }^{*}$ Level of significance $\mathrm{P}<0: 05 ; \mathrm{N}=$ number of subjects; $\mathrm{M}=$ means; $\mathrm{SD}=$ standard deviation.

Figure 1 shows the values for the median and quartile 1, which amount to 25 and $75 \%$, respectively, of the described values. The median VEGF levels were as follows: G1 $=394.6 \mathrm{pg} /$ $\mathrm{mL} ; \mathrm{G} 2=159.9 \mathrm{pg} / \mathrm{mL} ; \mathrm{G} 3=236.4 \mathrm{pg} / \mathrm{mL} ;$ and G4 $=269.3 \mathrm{pg} / \mathrm{mL}$. For AFP levels, the respective median values were $\mathrm{G} 1=439.5 \mathrm{ng} / \mathrm{mL} ; \mathrm{G} 2=2.7 \mathrm{ng} / \mathrm{mL} ; \mathrm{G} 3=3.0 \mathrm{ng} / \mathrm{mL} ;$ and $\mathrm{G} 4=2.6 \mathrm{ng} / \mathrm{mL}$. 
The correlation between serum levels of AFP and VEGF is shown in Figure 2. Low $R^{2}$ values were observed, which demonstrates a weak correlation between these variables in all groups. The ROC curve was used to evaluate the discriminatory power of each variable with significance level for all analyses $(P<0.05$; Figure 3$)$. The respective values of sensitivity and specificity for VEGF (Figure $3 \mathrm{~A}$ ) were 40 and $96 \%$ (area under the curve $(A \cup C)=0.709615$ ) when comparing patients with HCC (G1) and control subjects (G4). Sensitivity and specificity values were 50 and $85 \%$, respectively, (AUC $=0.69$ ) for $\mathrm{G} 1$ compared to $\mathrm{G} 3$, and were 65 and $85 \%$, respectively, $(A \cup C=0.8175$ ) for $\mathrm{G} 1$ compared to G2. For serum AFP levels (Figure 3B) there was an overlapping of lines indicating a sensitivity of $28 \%$ and a specificity of $99 \%$ when comparing $\mathrm{G} 1$ to $\mathrm{G} 3$ (AUC $=0.88$ ), G1 to G3 (AUC $=0.79$ ), or $\mathrm{G} 1$ to $\mathrm{G} 4$ (AUC = 0.78).

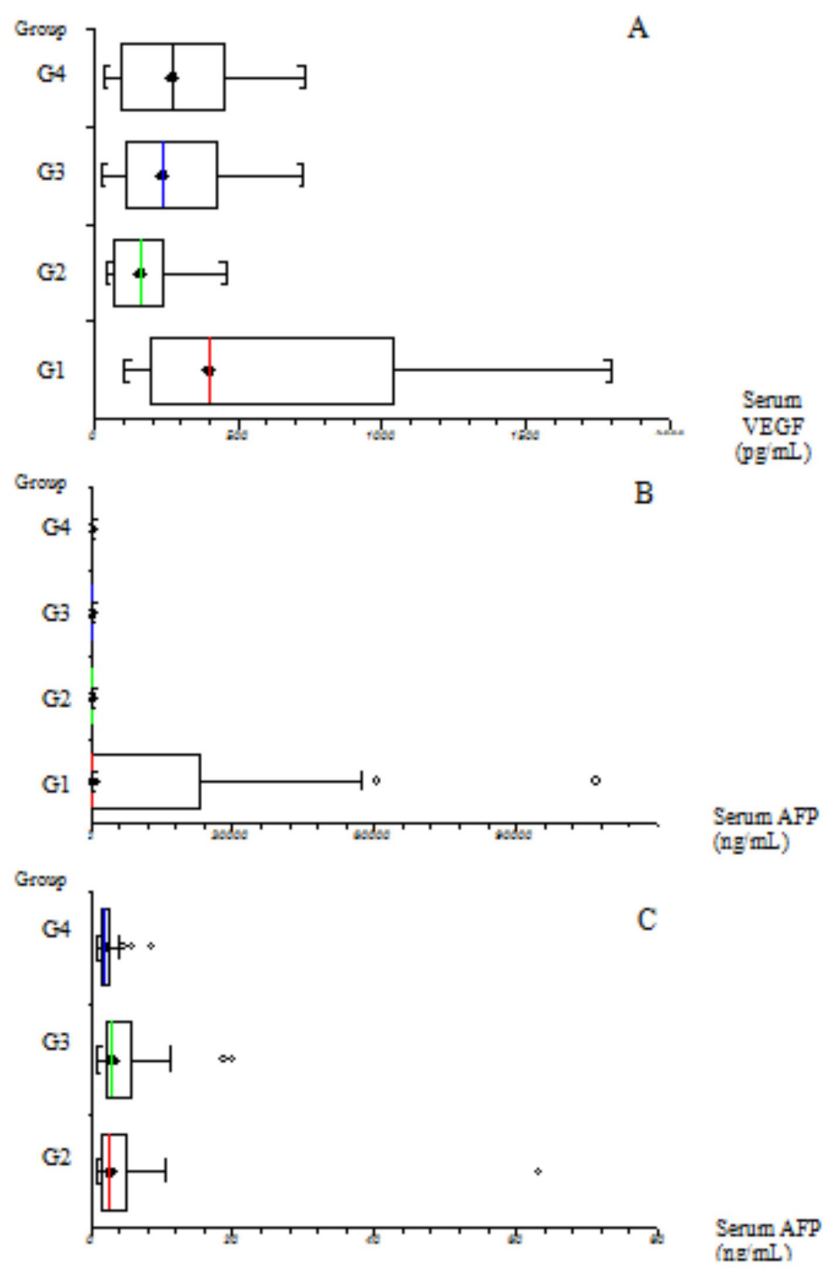

Figure 1. Representation of serum levels of (A) vascular endothelial growth factor (VEGF) and (B, C) alpha-fetoprotein (AFP) in box plots, indicating the maximum, minimum and median values. Values for quartiles $1(25 \%)$, represented by $F$, and $3(75 \%)$, represented by - , are shown in groups of patients with hepatocellular carcinoma (G1), cirrhosis (G2), or hepatitis C virus (G3), and the control group (G4). A. Box plot scale of $100 \mathrm{pg} / \mathrm{mL}$ on the abscissa; B. Box plot scale of $6000 \mathrm{ng} / \mathrm{mL}$ on the abscissa; and C. Box plot scale of $4 \mathrm{ng} / \mathrm{mL}$ on the abscissa. $=$ median; $\odot=$ outlier 
A

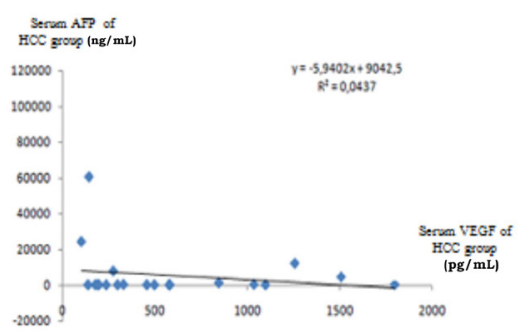

C

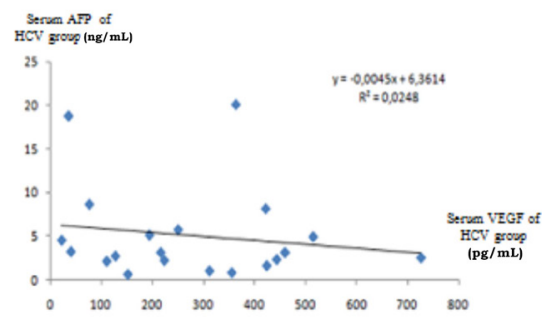

B

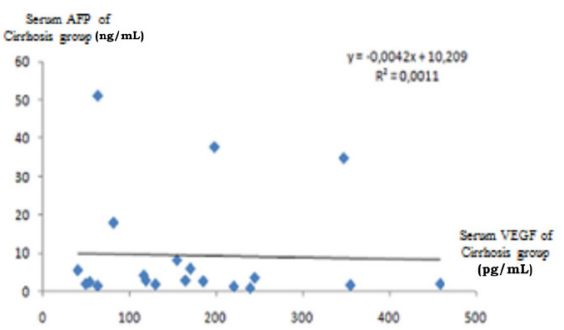

D

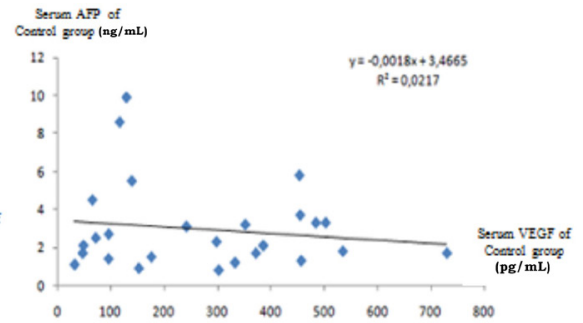

Figure 2. Pearson correlation between vascular endothelial growth factor (VEGF) and alpha-fetoprotein (AFP) in groups of patients with (A) hepatocellular carcinoma ( $\mathrm{HCC}),(\mathbf{B})$ cirrhosis, or (C) hepatitis $\mathrm{C}$ virus (HCV), and (D) the control group.

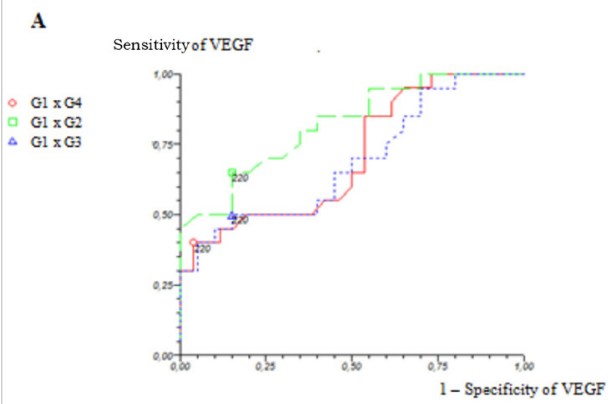

B Sensitivity of AFP

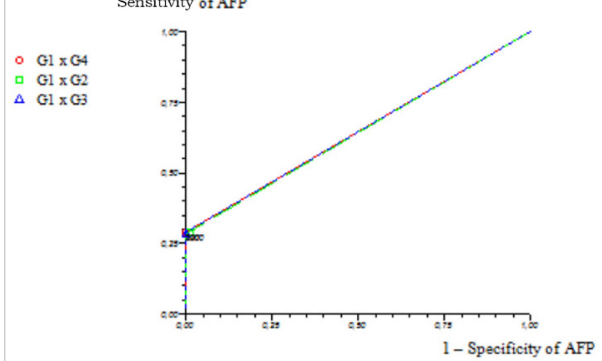

Figure 3. Receiver operator characteristic (ROC) curve with values for sensitivity and specificity of serum levels for $(A)$ vascular endothelial growth factor (VEGF) and (B) alpha-fetoprotein (AFP) in patients with hepatocellular carcinoma (G1), cirrhosis (G2), or hepatitis C virus (G3), and the control group (G4). 


\section{DISCUSSION}

In this study, the presence of the mutant allele (T) in the VEGF -C936T SNP shows a correlation with elevated serum VEGF levels, particularly in the group of patients with HCC. However, the distribution of this polymorphism was similar among all groups. Although the literature suggests there is an association of high serum level of VEGF with HCC (Poon et al., 2004), some studies have found the mutant allele of the VEGF -C936T SNP to be associated with lower plasma levels of VEGF (Renner et al., 2000; Jain et al., 2013), which is not corroborated by the findings in this study. An association between the mutant genotype (TT) of VEGF -C936T with nodal invasion for HCC has also been found, which is an indicator of poor disease prognosis (Kong et al., 2007). However, another study found that the carriers of the CC genotype are more susceptible to HCC development (Giacalone et al., 2011). It is possible that the profile of this series, including the recognized miscegenation of the Brazilian population (Lopes Maciel et al., 2011) and the small number of individuals studied have influenced this analysis.

The increase in serum VEGF levels in patients with HCC compared to those with cirrhosis or chronic hepatitis can be explained by a higher tissue transcript level of VEGF in the carcinoma (Sharma et al., 2013). This information matches the function of VEGF to promote neovascularization and endothelial cell proliferation, which are related to carcinogenesis (Grizzi et al., 2007). This study showed that serum VEGF level in patients with HCC was higher than in patients with cirrhosis. However, serum VEGF in cirrhosis patients was higher when compared with the control group $(P=0.037)$, diverging from data published by Mukozu et al. (2013) and Renner et al. (2000). Poon et al. (2004) showed no significant relationship between serum VEGF levels and cirrhosis but, similar to the current study, the median serum VEGF level was significantly higher in patients with HCC than in healthy controls $(P=0.042)$. Serum VEGF levels were also used to calculate sensitivity and specificity, with values of 65 and $85 \%$, respectively (reference value $=220$ $\mathrm{pg} / \mathrm{mL}$ ). Other studies have reported sensitivity and specificity values of 98 and $46 \%$, respectively, using a cut-off value of less than $108 \mathrm{pg} / \mathrm{mL}$ when comparing groups of patients with HCC and cirrhosis. These results indicate that tumor development in patients with cirrhosis can be detected through increasing serum levels of VEGF (Renner et al., 2000).

AFP has long been considered the ideal serological marker for the detection of HCC, particularly if its concentration is greater than $500 \mathrm{ng} / \mathrm{mL}$ (Gomes et al., 2013). The current study found sensitivity of $28 \%$ and specificity of $99 \%$ using a reference value of $200 \mathrm{ng} / \mathrm{mL}$. These values are similar to those observed by Trevisani et al. (2001) after adopting the same cut-off value (sensitivity of $22.4 \%$ and specificity of $99.4 \%$ ). On the other hand, in a review published by Daniele et al. (2004), overall sensitivity values were between 39 and $65 \%$ and specificity values were between 76 and $94 \%$ when comparing studies that predominantly used a cut-off value of $20 \mathrm{ng} / \mathrm{mL}$. This indicates the need for standardization of a reference value for AFP, which has not yet established.

Serum levels of VEGF and AFP showed weak correlation $\left(0.0011 \leq R^{2} \leq 0.0437\right)$ in all groups. Similar results were found by Poon et al. (2004). In contrast, el-Houseini et al. (2005) reported an increased sensitivity (95.5\%) for HCC when combining levels of AFP and VEGF, but with cut-off value for AFP > $19.8 \mathrm{ng} / \mathrm{mL}$ and VEGF > $355.2 \mathrm{pg} / \mathrm{mL}$. Meanwhile, the variables that were independently analyzed showed values of 68.2 and $86.4 \%$ for the respective indicators.

In this study, although no correlation between VEGF and AFP was found, the association between the mutant ( $\mathrm{T}$ ) allele of the VEGF -C936T polymorphism and increased levels of VEGF was found in patients with HCC. These factors could be used as potential indicators of the disease 
and should be confirmed in other populations. In conclusion, the VEGF -C936T polymorphism is not associated with $\mathrm{HCC}$; however, the presence of the mutant allele $(\mathrm{T})$ may increase serum VEGF levels in this group. Additionally, increased levels of VEGF differentiate patients with HCC from those with cirrhosis while AFP levels can be used to distinguish patients with $\mathrm{HCC}$ from those with cirrhosis or HCV. VEGF with a specificity of $85 \%$ is also a potential marker for HCC.

\section{Conflicts of interest}

The authors declare no conflict of interest.

\section{ACKNOWLEDGMENTS}

Research supported by Fundação de Amparo à Pesquisa do Estado de São PauloFAPESP (\#2012/19826-3, \#2012/11953-6 and \#2012/23619-3). We thank Marcelo Arruda Nakazone, Diretor Científico do Centro Integrado de Pesquisa-CIP (Hospital de Base/FAMERP), for his technical assistance, as well as Moacir Fernandes de Godoy for his support with the statistical data analyses.

\section{REFERENCES}

Asghar U and Meyer T (2012). Are there opportunities for chemotherapy in the treatment of hepatocellular cancer? J. Hepatol. 56: 686-695.

Bruix J and Sherman M (2011). Management of hepatocellular carcinoma: an update. Hepatology 53: 1020-1022.

Chan SL, Chan AT and Yeo W (2009). Role of alpha-fetoprotein in hepatocellular carcinoma: prognostication, treatment monitoring or both? Future Oncol. 5: 889-899.

Chan SL, Mo F, Johnson PJ, Siu DY, et al. (2014). Performance of serum a-fetoprotein levels in the diagnosis of hepatocellular carcinoma in patients with a hepatic mass. HPB 16: 366-372.

Daniele B, Bencivenga A, Megna AS and Tinessa V (2004). Alphafetoprotein and ultrasonography screening for hepatocellular carcinoma. Gastroenterology 127: S108-S112.

DiMarino AJ (2000). Therapy of digestive disorders: A companion to sleisenger and Fordtran's gastrointestinal and liver disease. Gastroenterology 118: 1275-1276.

el-Houseini ME, Mohammed MS, Elshemey WM, Hussein TD, et al. (2005). Enhanced detection of hepatocellular carcinoma. Cancer Control 12: 248-253.

Fattovich G, Stroffolini T, Zagni I and Donato F (2004). Hepatocellular carcinoma in cirrhosis: incidence and risk factors. Gastroenterology 127: S35-50.

Ferrara N, Gerber HP and LeCouter J (2003). The biology of VEGF and its receptors. Nat. Med. 9: 669-676.

Giacalone A, Montalto G, Giannitrapani L, Balasus D, et al. (2011). Association between single nucleotide polymorphisms in the cyclooxygenase-2, tumor necrosis factor- $\alpha$, and vascular endothelial growth factor-A genes, and susceptibility to hepatocellular carcinoma. OMICS 15: 193-196.

Gomes MA, Priollib DG, Tralhão JG and Botelho MF (2013). Hepatocellular Carcinoma: epidemiology, biology, diagnosis and therapies. Rev. Assoc. Med. Bras. 59: 514-524.

Grizzi F, Franceschini B, Hamrick C, Frezza EE, et al. (2007). Usefulness of cancer-testis antigens as biomarkers for the diagnosis and treatment of hepatocellular carcinoma. J. Transl. Med. 5: 3.

Jain L, Vargo CA, Danesi R, Sissung TM, et al. (2013). The role of vascular endothelial growth factor SNPs as predictive and prognostic markers for major solid tumors. Mol. Cancer Ther. 8: 2496-2508.

Kong SY, Park JW, Lee JA, Park JE, et al. (2007). Association between vascular endothelial growth factor gene polymorphisms and survival in hepatocellular carcinoma patients. Hepatology 46: 446-455.

Lopes Maciel LG, Ribeiro Rodrigues EM, Carneiro Dos Santos NP, Ribeiro Dos Santos Â, et al. (2011). Afro-derived Amazonian populations: inferring continental ancestry and population substructure. Hum. Biol. 83: 627-636.

Nishida N and Goel A (2011). Genetic and epigenetic signatures in human hepatocellular carcinoma a systematic review. Curr. Genomics 12: 130-137. 
Poon RT, Ho JW, Tong CS, Lau C, et al. (2004). Prognostic significance of serum vascular endothelial growth factor and endostatin in patients with hepatocellular carcinoma. Br. J. Surg. 91: 1354-1360.

Renner W, Kotschan S, Hoffmann C, Obermayer-Pietsch B, et al. (2000). A common 936 C/T mutation in the gene for vascular endothelial growth factor is associated with vascular endothelial growth factor plasma levels. J. Vasc. Res. 37: 443-448.

Schwartz M, Roayaie S and Konstadoulakis M (2007). Strategies for the management of hepatocellular carcinoma. Nat. Clin. Pract. Oncol. 4: 424-432.

Sharma BK, Srinivasan R, Kapil S, Singla B, et al. (2013). Angiogenic and anti-angiogenic factor gene transcript level quantitation by quantitative real time PCR in patients with hepatocellular carcinoma. Mol. Biol. Rep. 40: 5843-5852.

Trevisani F, D'Intino PE, Morselli-Labate AM, Mazzella G, et al. (2001). Serum a-fetoprotein for diagnosis of hepatocellular carcinoma in patients with chronic liver disease (influence of HbsAg and anti-HCV status). J. Hepatol. 34: 570-575.

van der Veek PP, de vos Tot Nederveen Cappel WH, Langers AM and Van Hoek B (2011). Two patients with extremely elevated tumor markers: where is the malignancy? Gastroenterol. Res. Pract. 2011: 123743.

Venkitaraman AR (2014). Tumour suppressor mechanisms in the control of chromosome stability: insights from BRCA2. Mol. Cells 28: 95-99.

Vezozzo DCP, Ono SK, Mora MVA, Farias AQ, et al. (2014). Epidemiology of HCC in Brazil: incidence and risk factors in a ten-year cohort. Ann. Hepatol. 13: 386-393.

Wolf G, Aigner RM, Schaffler G, Langsenlehner U, et al. (2004). The 936C>T polymorphism of the gene for vascular endothelial growth factor is associated with 18F-fluorodeoxyglucose uptake. Breast Cancer Res. Treat. 88: 205-208.

Zhan P, Qian Q and Yu LK (2013). Serum VEGF level is associated with the outcome of patients with hepatocellular carcinoma: a meta-analysis. Hepatobiliary Surg. Nutr. 2: 209-215.

Zhang L, Wang JN, Tang JM, Kong X, et al. (2012). VEGF is essential for the growth and migration of human hepatocellular carcinoma cells. Mol. Biol. Rep. 39: 5085-5093. 